\title{
ANALYSIS TREND OF MANPOWER PLANNING FROM INDONESIAN NAVY SOLDIER
}

\author{
Brillyandhi Setyarizky, Bambang Suharjo, Sunarta. \\ ${ }^{1}$ Indonesian Naval Technology College, \\ Bumimoro-Morokrembangan, Surabaya 60187, Indonesia
}

\begin{abstract}
The Indonesian National Armed Forces (TNI AL), as a state institution in accordance with Law number 34 of 2004 concerning the Indonesian National Army in article 9 points stated that the Navy had a role to carry out the duties of the TNI in the development and development of sea power forces. The form of the strength of the sea dimension owned by the Navy is the Organization and the main weapon system (Alutsista), therefore the Navy has a policy in conducting organizational development and defense equipment in order to achieve the ideal strength posture, where the consequences of changes in the development of the Navy force is the need for the right number of personnel to be able to support the implementation of organizational functions and defense equipment personnel. Man Power planning includes all activities including in determining the number of troop compositions at the right time in accordance with the policies and plans of the organization and personnel of defense equipment. In the Navy organization, personnel consist of Soldiers and Civil Servants where TNI soldiers are divided into 3 groups namely Officers, Non-Commissioned Officers and Enlisted. So to deal with threats in the future, a proper planning of Soldiers is needed, therefore forecasting methods using trend analysis can be used to assist in as a basic for future planning
\end{abstract}

Keywords: Manpower Planning, Forecasting, Trend Analysis.

\section{INTRODUCTION}

The Indonesian National Armed Forces (TNI $\mathrm{AL}$ ), as a state institution in accordance with Law number 34 of 2004 concerning the Indonesian National Army in article 9 points stated that the Navy had a role to carry out the duties of the TNI in the development and development of sea power forces. The form of the strength of the sea dimension owned by the Navy is the Organization and the main tool of the weapons system (Alutsista), therefore the Navy has a policy in conducting organizational development and defense equipment in order to achieve the ideal strength posture, where the consequences of changes in the development of the Navy force is the need for the right number of personnel to be able to support the implementation of organizational functions and defense equipment personnel. An organization needs a long-term policy to be able to survive in a dynamic situation.

Based on these thoughts it can be said that the planning of the number of personnel needs needed will adjust to the needs of the defense equipment and the existing organizational development. Therefore, without proper planning, an organization will have difficulty in determining the direction of policy if it requires additional personnel. For this reason, there is a need for planning and developing Human Resources (HR) which are basically a closed hierarchical structure that is subject to constant changes in the economy and government policies. Human resource planning is the core of HR management that will be used as a standard document for recruiting and structuring the composition in the organization (Hayati, D.I., 2014).
Human resource planning includes all activities including in determining the number of troop compositions at the right time in accordance with the policies and plans of the organization and personnel of defense equipment. In the Navy organization, the personnel consist of Soldiers and Civil Servants where TNI soldiers are divided into 3 groups namely Officers, Bintara and Tamtama, for which the planning is handled directly by the Navy Headquarters, in this case the Navy Personnel Staff with Administration and Personnel Services Indonesian Navy as the executor. In its implementation, Planning for officers, Bintara and Tamtama needs becomes more complex in relation to the needs of positions in the organization, where there is a period of work for promotion of rank to a higher level and the transfer of strata from the bottom up.

At present there are conditions where there is an excess in the number of Officers, Bintara and Tamtama at certain rank levels, there is also a shortage of Officers, Bintara and Tamtama compared to the needs of available positions as listed in Table 1.1. This condition is a long-term effect that occurs due to government policies in increasing retirement age from 55 years to 58 years in the Officers group, and the recruitment of large numbers of personnel in the period 1999 to 2003 and demands from the leadership of the Navy to increase rank of Officer who has reached the time / is eligible. So that this can result in some officers having no position, which will certainly affect the performance, motivation and morality of the officer concerned. 
It turns out that this policy is now starting to lead to the Bintara and Tamtama classes where there is a discourse about the retirement age of the Bintara and enlisted retirement groups from the retirement age of 53 to 58 according to the current officer class.

It turns out that this policy is now starting to lead to the Bintara and Tamtama classes where there is a discourse about the retirement age of the Bintara and enlisted retirement groups from the retirement age of 53 to 58 according to the current officer class.

Therefore, if the planners of Human Resources in the Indonesian Navy currently want to have the right, effective and efficient organization as needed, this is called the Ideal Warrior force. So the planning staff in the personnel section of the organization must be able to be able to control the number of personnel needs in the organization and defense equipment personnel, the number of personnel for each rank, and the time in rank for each personnel is adjusted to the needs of the organization and the defense system personnel. So that it is expected that the trend model obtained from this study can help the current Human Resources planner in the Indonesian Navy.

\section{MATERIAL AND METHODS.}

\subsection{Manpower Planning.}

In meeting the needs of its personnel, the Navy requires proper planning in order to be able to run the wheels of the organization well so that the need for a theory that supports the planning of personnel needs where the theory that can support this is Manpower Planning (MPP) or planning of labor needs or often also called as Human Resource Planning $(\mathrm{HR})$ is one of the strategic tasks of every Human Resources (HR) practitioner whose job is to place the right number of people, the right people in the right place, the right time, doing the right thing and suitable for achieving organizational goals (Hayati, DI, 2014).

Although HR planning is prepared by Staff / Manpower Planners, Supervisors, HR Managers, and Managers in various fields, it is important to understand that employee needs cannot be separated from the organization's strategic plan in the next few years, in addition to needs that are based on aspects of the organization's operations currently. Human resource planning is an activity that is continuous due to circumstances and situations always changing by development, growth, globalization and demands (Hutapea, A., 2004). A good HR needs planning must be based on a number of considerations and methodologies, not only based on Workload Analysis.

HR planning must be a systems approach and be carried out within established procedures. The procedure that must be carried out is as follows:
a. Analyze current labor availability
b. Make workforce estimates in the future
c. Develop work programs
d. Design a training program

\subsection{Analisis Trend.}

Trend Analysis is a method of data analysis that aims to make estimates in the future to see an increasing or decreasing trend in a variable, over a certain period of time. Trend analysis in this study was used to determine trends from each rank within each class stratum.

The trend analysis uses the least square method (Least Square Method) to find the trend line, which is an estimate of the values of $a$ and $b$, so that the sum of the least squares error (minimum). The formula used is:

$$
\begin{aligned}
& \mathrm{Y}=\mathrm{a}+\mathrm{bx} \\
& \text { Where : } \\
& \mathrm{Y}=\text { Periodic data (land area, production and } \\
& \text { productivity) } \\
& \mathrm{a}=\text { constant } \\
& \mathrm{b}=\text { Regression coefficient } \\
& \mathrm{x}=\text { Time }
\end{aligned}
$$

Forecasting is a prediction, projection or estimation of the level of uncertain events in the future. Absolute accuracy in predicting events and the level of activities that will come is not possible to achieve, because when companies can not see events that will come with certainty, it takes a lot of time and effort so that they have the power to draw conclusions about future events.

\section{RESULTS AND DISCUSSION.}

The research used in writing this thesis is a quantitative method. Quantitative Method is a research method based on the philosophy of positivism, used to examine a particular population or sample, data collection using primary data and secondary data regarding the development of the strength of Navy personnel, quantitative / statistical data analysis, with the aim of testing hypotheses that have been set

In this study the authors collected data using primary data collection methods obtained from the report of the strength of the soldiers by the Navy personnel.

This research uses secondary and primary data. The data used in this study are secondary data obtained from the Navy Personnel Administration Office. in the form of the number of forces of the Indonesian Navy from 2007 to 2017.

In the discussion the percentage of ranks will be discussed with the data obtained from 2007 starting from the rank of officers displayed in the form of a trend graph as follows: 
Figure 1 Graphic Navy High Officers Trends

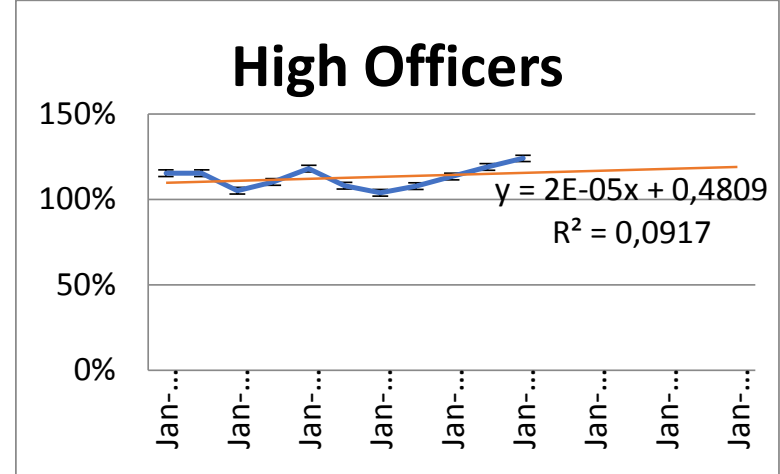

In the graph above illustrates that the graph percentage of high officers can be approached with a linear line so that the equation $y=2 E-05 x+0.4809$ is obtained. from these graphs illustrate that chart patterns tend to be stable in the range of $100 \%$ to $120 \%$.

Figure 2. Graphic Trend of the Navy Colonel

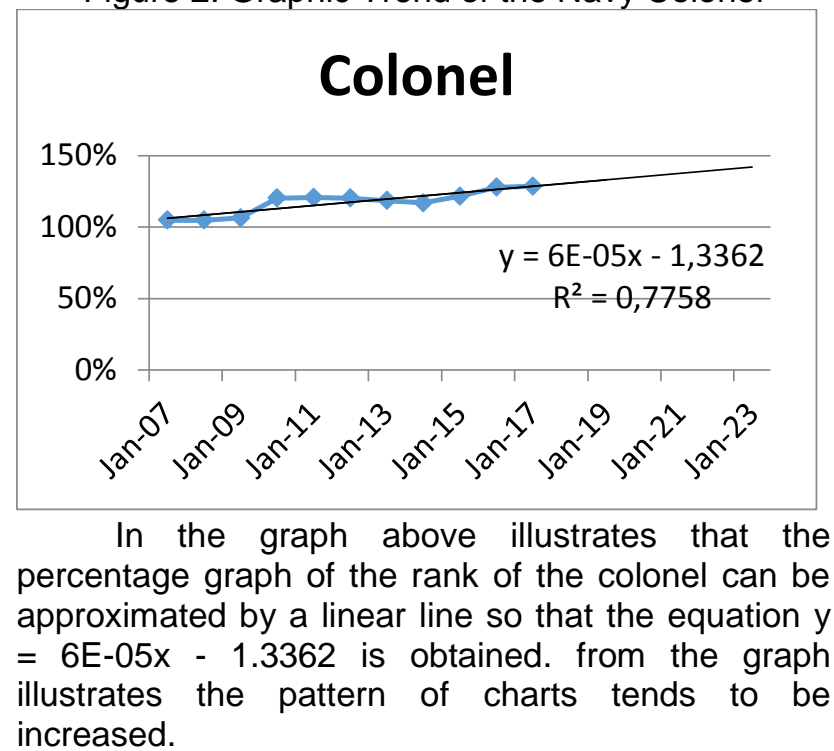

Figure 3 Graphic of Lieutenant Colonel Navy Rank.

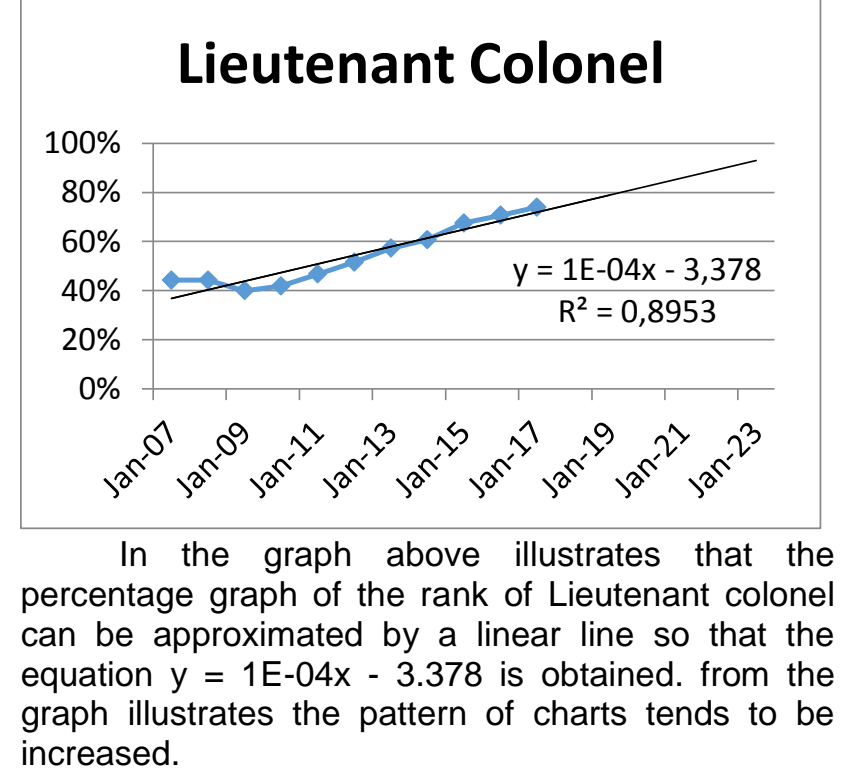

Figure 4. Graphic of Navy Major Rank.

\section{Major}

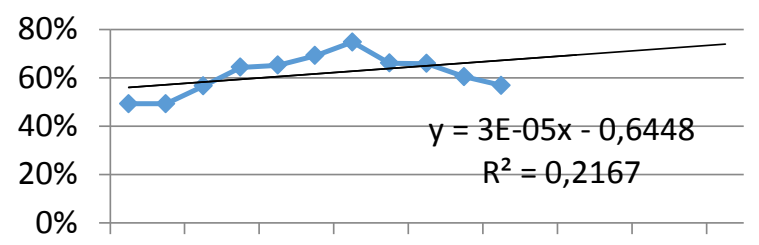

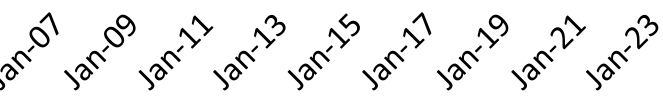

In the graph above illustrates that the percentage graph of the rank of major can be approximated by a linear line so that the equation $y$ $=3 E-05 x-0.6448$ is obtained. from the graph as well as at the rank of colonel and letko at the rank of major also illustrates the pattern of charts tends to be increased.

Figure 5. Graphic Trend of Captain of the Navy

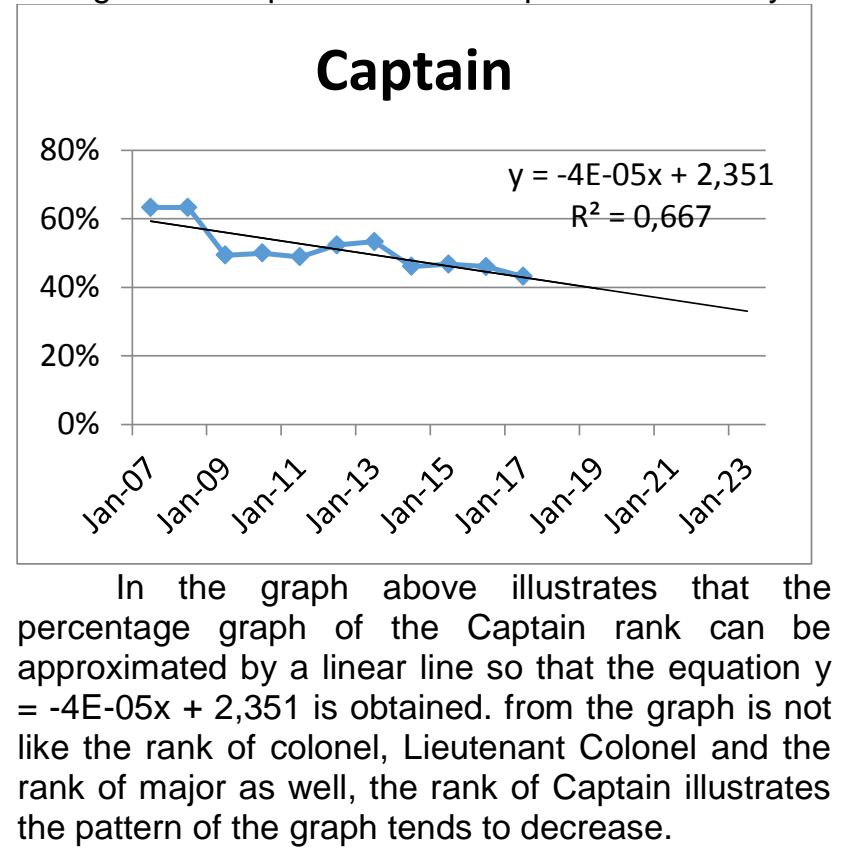

Figure 6. Graphic Navy First Lieutenant Trend Graph.

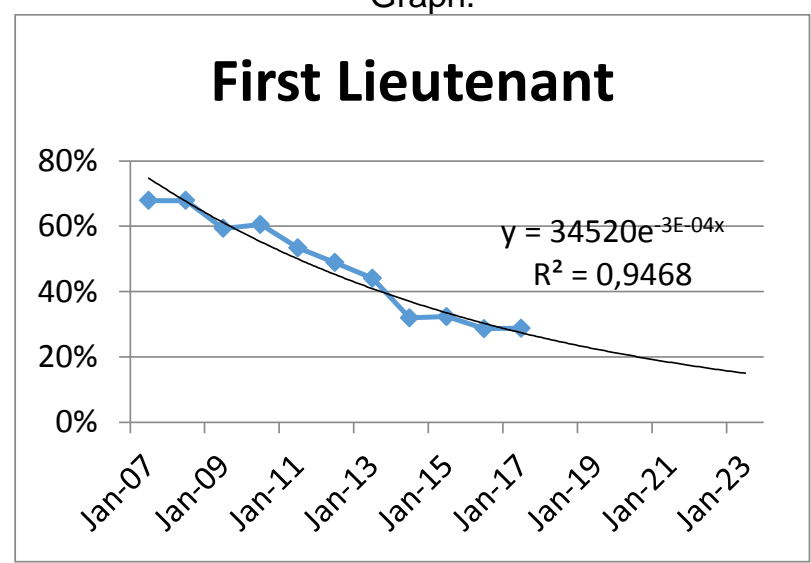

In the graph above illustrates that the graph of the percentage of rank First Lieutenant can be 
approached by the Exponential line so that the equation $y=34520 \mathrm{e}-3 \mathrm{E}-04 \mathrm{x}$ is obtained. from the graph as well as in the rank of captain, in the rank of the first graph illustrates the pattern tends to decrease.

Figure 7. Graphic Trend of Second Lieutenant of the Navy.

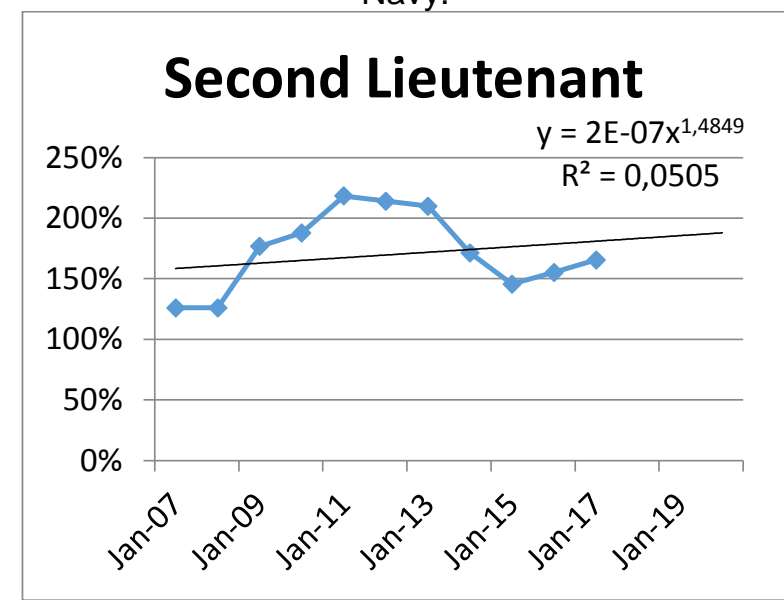

In the graph above illustrates that the percentage graph of Letda's rank can be approximated by a linear line so that the equation $y$ $=2 \mathrm{E}-07 \times 1.4849$ is obtained. from the graph is not like the rank of colonel, Lieutenant Colonel and the rank of major as well, the rank of Captain illustrates the pattern of the graph tends to Stabilizes.

After describing the condition of the trend in the rank in the class of officers will then be presented a description of the trend in the rank in the group of non-commissioned officer.

Figure 8. Graphic Trend of Navy Peltu Rank.

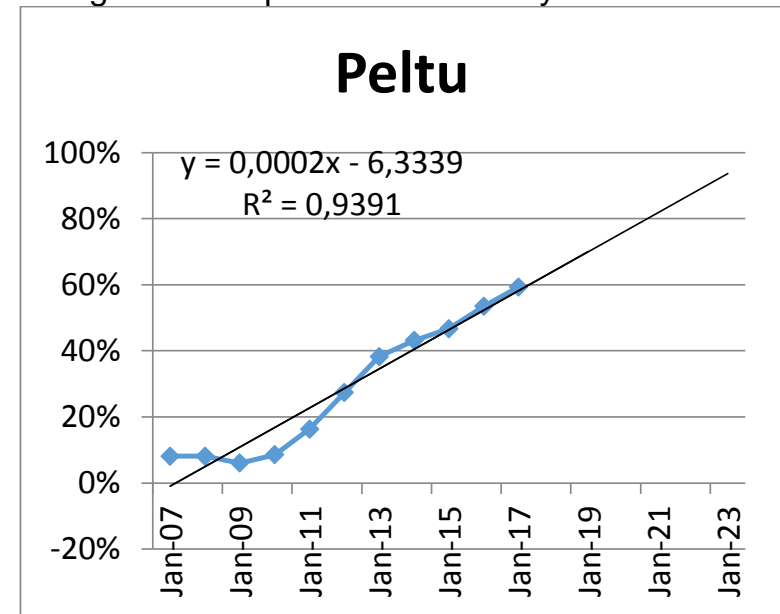

In the graph above illustrates that the percentage graph of the Peltu rank can be approximated by a linear line so that the equation $y$ $=0.0002 x-6.3339$ is obtained. from the graph as well as in the rank of colonel, Lieutenant Colonel and the rank of major as well, in the rank of Peltu illustrate the pattern of charts tends to be increased.
Figure 9. Graphic Trend of Navy Pelda Rank.

\section{Pelda}

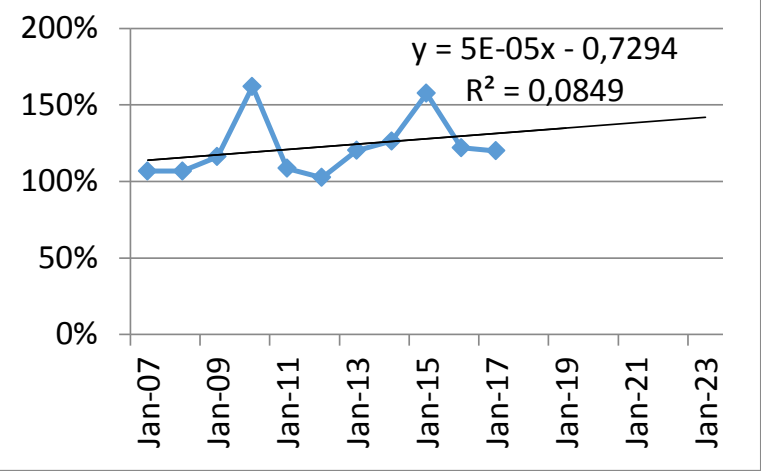

In the graph above illustrates that the percentage graph of the Peltu rank can be approximated by a linear line so that the equation $y$ $=5 \mathrm{E}-05 \mathrm{x}-0.7294$ is obtained. from the graph as in the Peltu rank, the Pelda rank illustrates that the chart pattern tends to increase.

Figure 10. Graphic Trend of Indonesian Navy Serma Rank.

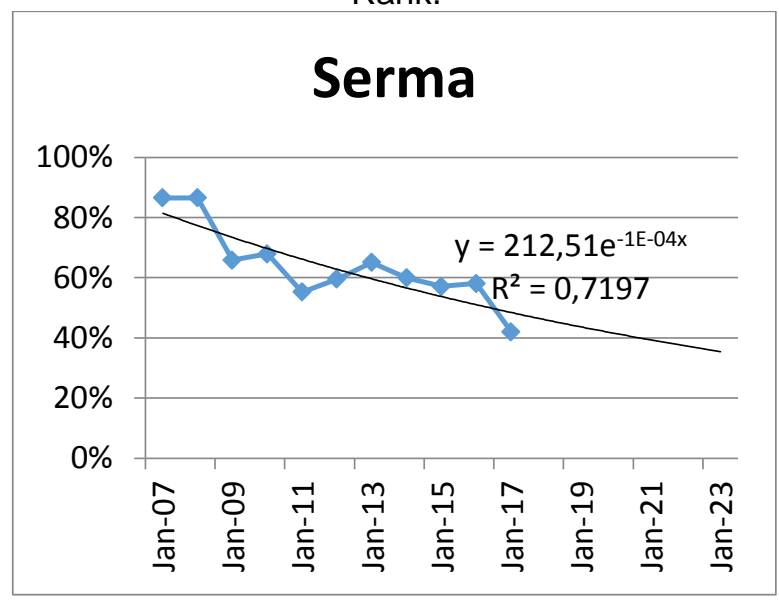

In the graph above illustrates that the percentage graph of the rank of Serma can be approximated by an exponential line so that the equation $y=212.51 \mathrm{e}^{-1 \mathrm{E}-04 \mathrm{x}}$ is obtained. from the graph, unlike the rank of Peltu and Pelda, the rank of Serma illustrates that the chart pattern tends to decrease.

Figure 11. Graphic Trend of the Navy Serka Rank.

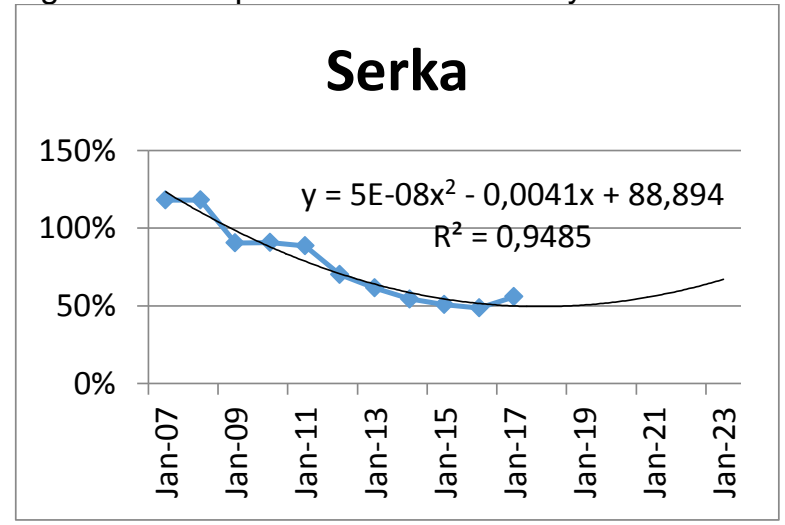


In the graph above illustrates that the percentage graph of the rank of Serka can be approximated by the Polynomial line so that the equation $y=5 E-08 x^{2}-0.0041 x+88.894$ is obtained. from the graph as well as in the rank of Serma, in the rank of Serka illustrates the pattern of the graph tends to decrease.

Figure 12. Graphic Trend of Navy Sertu Rank.

\section{Sertu}

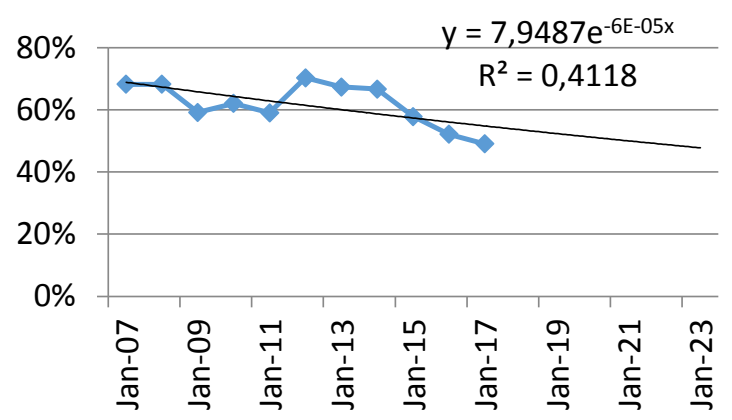

In the graph above illustrates that the percentage graph of the rank of Sertu can be approached with an exponential line so that the equation $y=7.9487$ e- 6 E- $05 x$ is obtained. from the graph as well as in the rank of Serma, the rank of Seru illustrates that the chart pattern tends to be downward.

Figure 13. Graphic Trend of Navy Serda Rank.

\section{Serda}

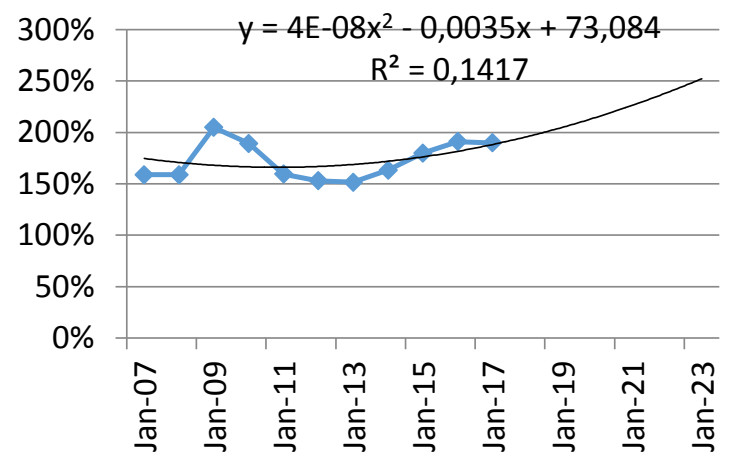

In the graph above illustrates that the percentage graph of the rank of Serda can be approximated by the Polynomial line so that the equation $y=4 \mathrm{E}-08 \times 2-0.0035 x+73.084$ is obtained. from the graph as is the case with the rank of Serma, the rank of Serda illustrates that the chart pattern tends to increase.

After describing the condition of the trends in the ranks in the ranks of officers and noncommissioned officer will then be presented a description of the trends in the ranks of the Enlisted class
Figure 14. Graphic Trend of Navy Koptu Rank.

\section{Kopka}

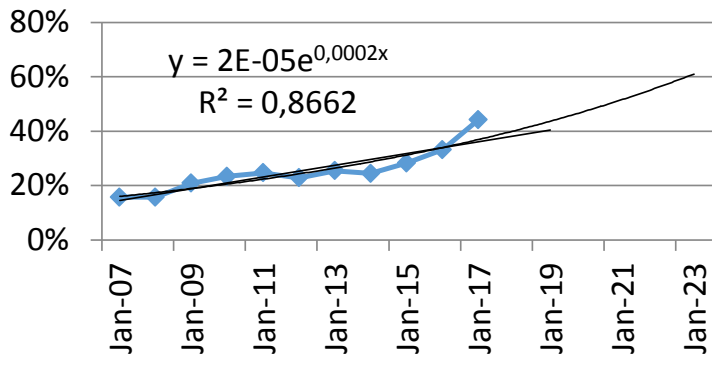

In the graph above illustrates that the percentage graph of the rank of Kopka can be approached with an exponential line so that the equation $y=72 \mathrm{E}-05 \mathrm{e}^{0.0002 x}$ is obtained. from the graph as in the other ranks, the rank of Kopka illustrates that the chart pattern tends to increase.

Figure 15. Graphic Trend of Navy Koptu Rank.

\section{Koptu}

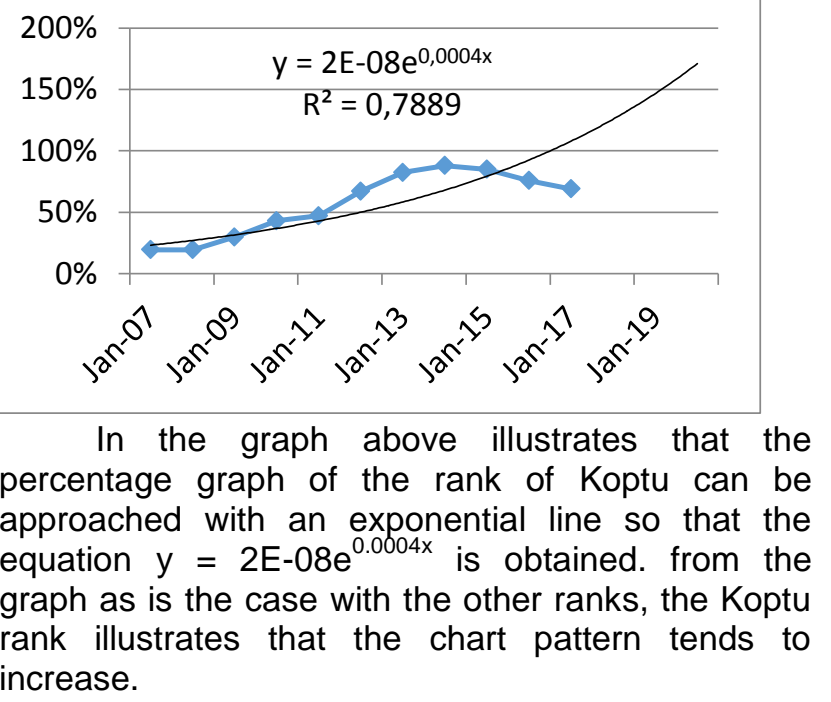

Figure 16. Graphic Trend of Navy Kopda Rank.

\section{Kopda}

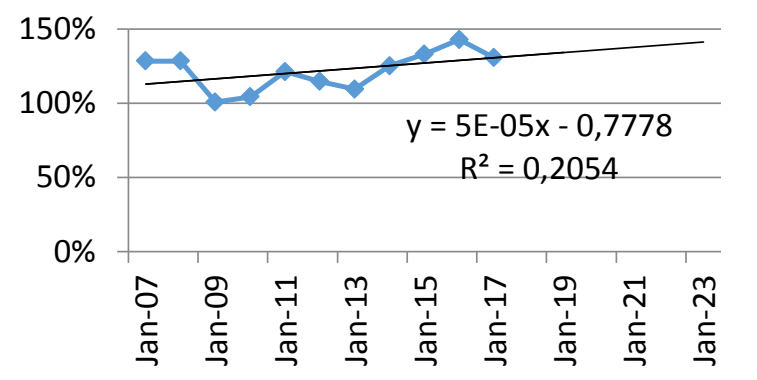

In the graph above illustrates that the percentage graph of the rank of Kopda can be approached with a linear line so that the equation $y$ $=5 \mathrm{E}-05 \mathrm{x}-0.7778$ is obtained. from the graph as in 
the other ranks, the rank of Kopda illustrates that the chart pattern tends to increase.

Figure 17. Graphic Trend of Navy KLK Rank.

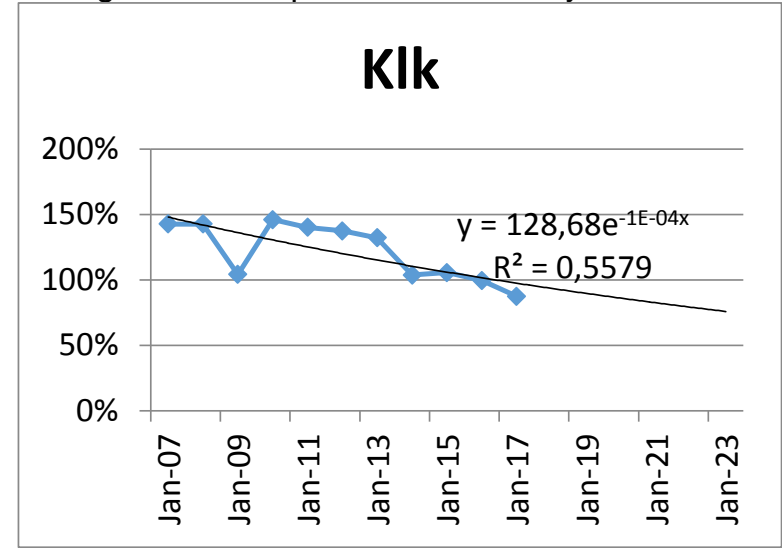

In the graph above illustrates that the percentage graph of the rank of flatfoot can be approached with an exponential line so that the equation $y=128.68 e^{-1 \mathrm{E}-04 \mathrm{x}}$ is obtained. from the graph as is the case with the other ranks, the Klk rank illustrates that the chart pattern tends to decrease

Figure 18. Graphic Trend of Navy KLS Rank.

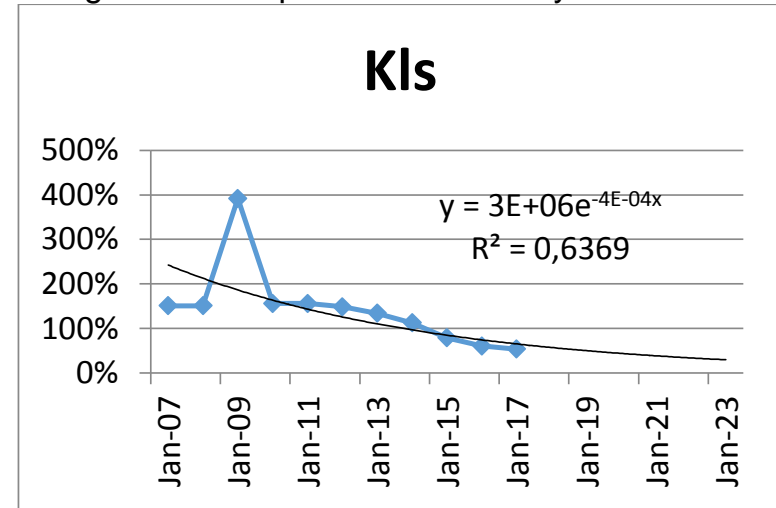

In the graph above illustrates that the graph of the percentage of the rank of One Line can be approached with an exponential line so that the equation $y=3 E+06 e^{-4 E-04 x}$ is obtained. from the graph as well as at other ranks, at the rank Kls illustrates that the chart pattern tends to decrease.

Figure 19. Graphic Trend of Navy KLD Rank.

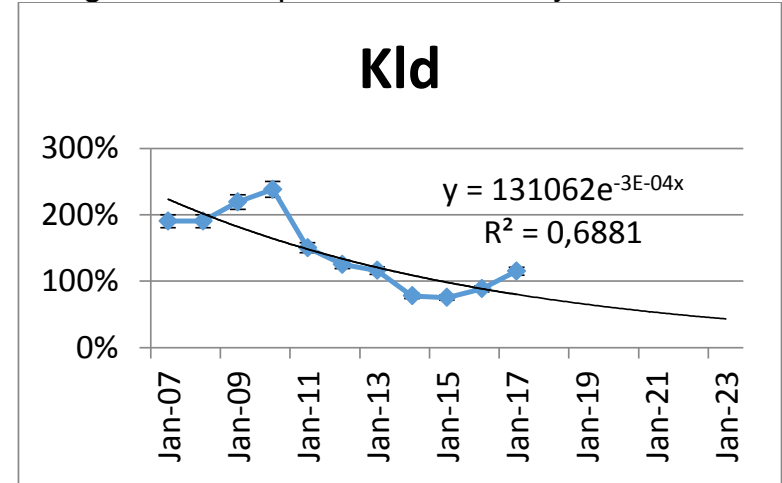

In the graph above illustrates that the percentage graph of the rank of Flatfoot Two can be approached with an exponential line so that the equation $y=131062 e^{-3 E-04 x}$ is obtained. from the graph as well as at other ranks, at the Kld rank illustrates that the chart pattern tends to decrease.

\section{CONCLUSION}

The results of the Strength Analysis of the Officers' class show that in the rank of Major and above the fulfillment of the soldiers has exceeded the needs so that there is a need for new office space to overcome the increasing percentage of the growth in the number of soldiers in the rank of major and above, while with a cheerful breadth of positions in the rank of letda to the captain then can be increased revenue from the education formation of officers formation (Dlktukpa) so that it will not burden on the rank of major and above because the input of Diktukpa officers has a very short rank at the secondary officer level.

In the Bintara Group, it appears that the recruitment of Diktukpa Soldiers succeeded in reducing the number of soldiers in the ranks of Serka and Serma, but in the rank of peltu and pelda there was still a fulfillment of the number of soldiers.

Whereas in the enlisted class the number of soldiers in the rank of the Chief of the Navy (KLK) decreased in terms of the percentage of filling positions than previously had the number of replenishment more than $100 \%$ as the road had returned to the number of personnel filling around $100 \%$. this shows the number of enlisted recruits was in accordance with needs.

\section{REFERENCES}

Sugiyono (2004), Business Research Methods, CV. Alfabeta, Bandung

AT. Mahan ,. 1960-1783, The Influence of Sea Power Upon History, Twelfth Edition, Boston, Little Brown and Company, p. 82

RI Law Number 37 of 1999 dated September 14, 1999 concerning Foreign Relations.

J.G. Starke, (1989), Introduction to International Law (An Introduction on International Law), Translation of Sumitro Danuredja and Lukas Ginting, (Jakarta: Aksara Persada Indonesia, p. 143

Moenir (1998). General Service Management. Jakarta: Bumi Aksara, p. 116.18

Mochtar Kusumaatmadja, 1990, "Introduction to International Law", Bandung: Binacipta, p. 11 